${ }^{1}$ Balıkesir Üniversitesi Tıp Fakültesi İç Hastalıkları Anabilim Dalı, Balıkesir, Türkiye

e-posta:

mdbalkes10@gmail.com ORCID: 0000-0002-6111-0030

${ }^{2}$ Balıkesir Üniversitesi Tıp Fakültesi İç Hastalıkları Anabilim Dalı, Endokrinoloji ve Metabolizma Hastalıkları Bölümü, Balıkesir, Türkiye e-posta:

drmustafaeroglu@gmail.com ORCID: 0000-0002-7526-7151

Atıf İçin: Uğur ERGÜN, Mustafa EROĞLU, Hirsutizmli Hastada Sertoli Leydig Hücreli Over Tümörü, Balıkesir Medical Journal, 2020;4(2): 13-16

Başvuru Tarihi: 11.03.2020 Kabul Tarihi: 09.06.2020 Yayınlanma Tarihi: 23.06.2020

Sorumlu Yazar:

Uğur Ergün,

Balıkesir Üniversitesi Tıp

Fakültesi İç Hastalıkları Anabilim Dalı, Balıkesir, Türkiye

e-posta:

mdbalkes10@gmail.com

\section{Hirsutizmli Hastada Sertoli Leyding Hücreli Over Tümörü}

\author{
Sertoli Leyding Cell Ovarian Tumor in a Patient with Hirsutism
}

\author{
Uğur Ergün ${ }^{1}$, Mustafa EROĞLU²
}

Öz

Hiperandrojenizm; kadınlarda hirsutizm, akne, alopesi gibi belirtilere neden olan androjen fazlalığı durumudur. Hirsutizm ise kadınlarda androjene duyarlı bölgelerde erkek tipi kıllanma artışıdır. Hiperandrojenizmin birçok nedeni bulunmaktadır. Androjen salgılayan over ve adrenal tümörler hiperandrojenizmin nadir görülen nedenlerindendir. Özellikle klinik tablonun hızlı ilerlediği, virilizasyon bulgularının eşlik ettiği androjen düzeylerinin çok yüksek olduğu olgularda over ya da adrenal kaynaklı tümörler akla gelmelidir. İzole total testosteron düzeyi $4,15 \mathrm{ng} / \mathrm{mL}$ olan ve görüntülemede lezyon saptanmayan postmenopozal kadın hastada bilateral ooforektomi sonrası hiperandrojenizmin nadir bir nedeni sertoli leyding hücreli over tümör tanısı konuldu.

Anahtar Kelimeler: Hirsutizim; testosteron; over tümörü; postmenopozal

\section{ABSTRACT}

Hyperandrogenism is a condition of androgen excess that causes symptoms such as hirsutism, acne and alopecia in women. Hirsutism is the increase of male pattern hair growth in androgen sensitive areas in women. There are many causes of hyperandrogenism. Androgen-secreting ovarian and adrenal tumors are among the rare causes of hyperandrogenism. Ovarian or adrenal-induced tumors should be considered especially in cases where the clinical picture progresses rapidly and the levels of androgen accompanied by virilization are very high. A rare cause of hyperandrogenism after bilateral oophorectomy was diagnosed with sertoli leyding cell ovarian tumor in a postmenopausal female patient with isolated total testosterone level of $4.15 \mathrm{ng} / \mathrm{mL}$ and no lesion was detected on imaging.

Keywords: Hirsutism; testosterone; ovarian tumor; postmenopausal 
Hiperandrojenizm reprodüktif dönemdeki kadınlarda yaygın olarak görülen bir durumdur. Klinikte hiperandrojenizmin belirtisi olarak hirsutizm, akne, alopesi, ovulatuvar disfonksiyon ya da daha ağır bulgu virilizm görülür. Hiperadrojenezimin en sık nedeni polikistik over sendromu olup diğer nedenleri ise idiyopatik hiperandrojenizm, obezite, cushing hastalığı, ciddi insülin direnci, hiperprolaktinemi, kongential adrenal hiperplazi, over ve adrenal tümörleridir (1). Over ve adrenal kaynaklı tümörler yüksek androjen düzeylerine ve bunun sonucu olarak da klinik tablonun hızı ilerlemesine ve virilizasyon bulgularına yol açarlar. Özellikle virilizan over tümörü kaynaklı hiperandrojenizmin bulguları daha çok ileri yaşlarda ve hızlı bir şekilde ortaya çıkar. Bunların içerisinde ise en sık sertoli leyding hücreli tümörler yer alır (2). Tanıda pelvik ultrasonografi (US) ilk tercihtir. Pelvik US ile lezyon saptanmadığı durumda manyetik rezonans görüntüleme (MRG) tanıya yardımcı olmaktadır. Özellikle total testosteron düzeyi 1,5 ng/mL (150 ng/dL<) olup görüntüleme yöntemlerinde adrenal ve over kaynaklı bir lezyon saptanmaması durumunda overyan venöz örnekleme yapılır. Selektif over venöz örnekleme fertilite isteği nedeniyle premenopozal kadınlarda tercih edilir. Ancak postmenopozal kadınlarda daha çok iki taraflı ooforektomi yapılması uygundur (3). Bu yazımızda hirsutizm kliniği ve izole total testosteron yüksekliği nedeniyle direkt ooforektomi sonrasında over tümörü tanısı alan olgu sunuldu.

\section{OLGU SUNUMU}

58 yaşında kadın hasta son bir yıldır devam eden tüylenme artışı şikâyeti ile polikliniğimize başvurdu. Özgeçmişinde 15 yıl önce menapoz öyküsü ve astım tanısı bulunmaktaydı. Montelukast ve salbutamol dışında ilaç kullanımı yoktu. Fizik muayenede üst dudak, çene altı, ön kollar, alt karın ve uyluk bölgesinde hirsutizm dışında patolojik bulgu saptanmadı. Ferriman Gallwey (F-G) skalası ile hirsutizm skoru 24 ölçüldü. Laboratuvar testlerinde hemogram ile biyokimyasal tetkikleri olağan idi. Tiroid stimülan hormon (TSH): 0,6 $\mu$ IU/ml, prolaktin 6,71 ng/mL, 1 mg'lık deksametazon süpresyon testi kortizol seviyesi 0,74 $\mu \mathrm{g} / \mathrm{dL}$ ölçüldü ve tiroid hastalığı, hiperprolaktinemi ve cushing sendromu dışlandı. Total testosteron: 4,15 ng/mL (450 ng/dL) ölçüldü, bu değer kadın için over tümörü ya da adrenal tümör kaynaklı olabilecek düzeyde $(1,5 \mathrm{ng} / \mathrm{mL}<)$ yüksek idi. Dehidroepiandrosteron (DHEAS): 60,6 ug/dL olarak ölçüldü. DHEAS yüksek olmadığı için surrenal bez patolojileri düşünülmedi. Total testosteron yüksekliğinin over kaynaklı olduğu düşünüldü. Çekilen pelvik US ve MRG'de bilateral overler normal görünümde idi. Kontrol testosteron seviyesi 4,34 ng/mL ölçülen hastada görüntüleme normal olsa da hiperandrojenizm nedeni olarak MRG incelemesinde saptanması güç olan boyutları küçük over tümörü düşünüldü. Hastamız postmenopozol dönemde olduğundan overler non fonksiyone olup infertilite endişesine de gerek olmadığı için over venöz örnekleme incelemesi yapılmaksızın ooforektomi yapılmasına karar verildi. Hasta bilateral ooferektomi için kadın ve doğum hastalıklarına gönderildi. Bilateral oofoektomi uygulanan hastanın 3.ay kontrol muayenesinde total testosteron <0,1 ng/mL ve DHEAS: $34,7 \mathrm{ug} / \mathrm{dL}$ olarak ölçüldü. Postoperatif total testosteron düzeyi düşmesi ile hastanın androjen salgılayan tümör dokusunun çıkarılmış olduğu görüldü. Postoperatif spesmenlerin histopatolojik incelemesinde sertoli leydig hücreli tümörü saptandı (Resim 1). 


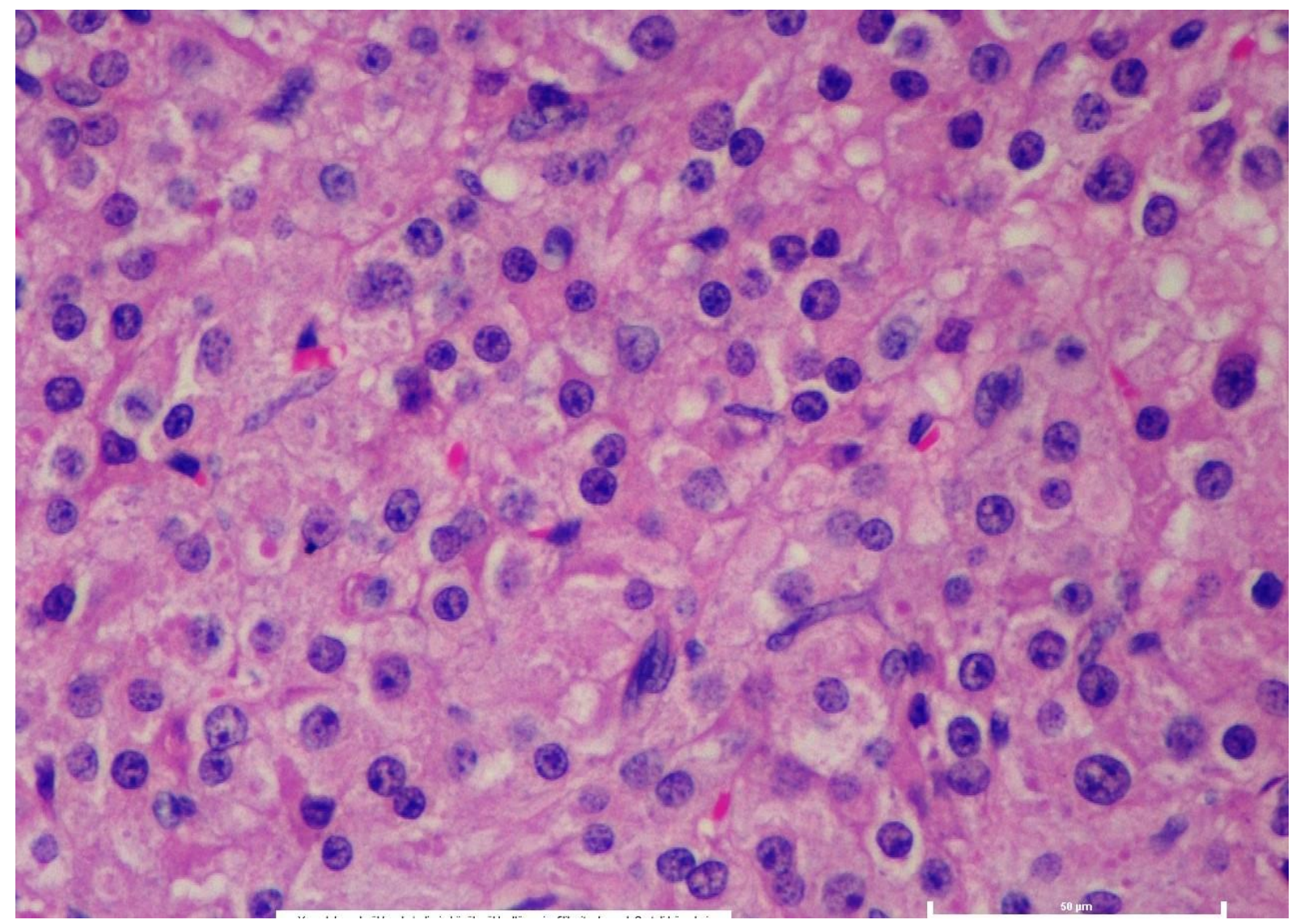

Resim 1. Yuvarlak oval nükleuslu belirgin küçük nükleollu eozinofilik sitoplazmalı sertoli hücreleri (40 X).

\section{TARTIŞMA}

Hiperandrojenizmin ciddi seyrettiği olgularda özellikle over ve adrenal kaynaklı tümörler ön planda düşünülmelidir. Tanıda ilk olarak total testosteron düzeyi ölçülmesi önemlidir. Total testosteron düzeyi 1,5 $\mathrm{ng} / \mathrm{mL}(150 \mathrm{ng} / \mathrm{dL}<$ ) olan olgularda ayırıcı tanıda adrenal ya da over tümörleri düşünülmelidir. Genelikle adrenal kaynaklı tümörlerde DHEAS düzeyi 700 uq/dl'den yüksek beklenir (4,5). Görüntülemede pelvik US, MRG ve diğer yöntemler kullanılır. Adrenal tümörler genellikle büyük boyutlu olup görüntülemede saptanır. Virilizan over tümör boyutlarının küçük olması nedeniyle çoğu zaman görüntülemede saptanamamaktadır. Bu durumda selektif over venöz örnekleme lezyonları tespit etmede yardımcıdır. Ancak venöz örnekleme daha çok overi fonksiyone ve fertilite gereken premenopozal kadınlara yapılır. Çocuk doğurma isteği olmayan premenopozal ya da postmenopozal kadınlarda tedavi seçeneği venöz örnekleme yapılmaksızın bilateral ooforektomi yapılmasıdır (6).

Olgumuzda total testosteron düzeyinin yüksekliği ile DHEAS'in normal olması over tümör kaynaklı hiperandrojenizmi düşündürdü. Hasta postmenopozal dönemdeki olduğu için venöz örnekleme incelemesi yapılmaksızın bilateral ooforektomi yapıldı. Postoperatif total testosteron düzeyi düştü ve histopatolojik inceleme virilizan sertoli leydig hücreli over tümörü ile uyumlu bulundu. Postmenopozal ya da ileri yaşta ciddi hiperandojenizmin kliniği ile başvuran olgularda tanıya yönelik cerrahi seçenek ön planda tutulabilir. Böyle olgularda venöz örnekleme incelemesi yapılması tanı ve tedavide zaman kaybına neden olabilir. 
Over tümörlerinin yaklaşık \%5’i androjen salgılayan tümörlerdir. Klinik belirti ve bulguları genellikle yaşamın ileri dönemlerinde hızlı bir şekilde ortaya çıkar. Virilizan over tümörleri içerisinde de en sık sertoli leyding hücreli tümörler yer alır. Granüloza teka hücreli tümörler, hilus hücreli tümörler ve brenner tümörler de diğer androjen salgılayan tümörlerdir (7).

Sonuç olarak, ciddi hiperandrojenizm kliniği ile başvuran özellikle de ileri yaş olgularda öncelikle over tümörü ve adrenal tümör düşünülmelidir. Genellikle virilizan over tümör boyutlarının küçük olması nedeniyle görüntüleme yöntemlerinde lezyon saptanamamaktadır. Bu durumun tanı ve tedavide gecikmelere yol açmaması adına postmenopozal kadınlarda direkt ooforektomi girişimi gerektiğini düşünüyoruz.

\section{KAYNAKLAR}

1. Markovski M, Hall J, Jin M, Laubscher T, Regier L. Approach to the management of idiopathic hirsutism. Can Fam Physician 2012;58;173-7.

2. Blume U. An overview of unwanted female hair. Br J Dermatol 2011;165;19-23.

3. Escobar HF. Diagnosis and management of hirsutism. Ann N Y Acad Sci 2010;1205:166-74.

4. Castelo C, Cancelo MJ Comprehensive clinical management of hirsutism. Gynecol Endocrinol 2010;26:484-93.

5. Paparodis R, Dunaif A. The Hirsute woman: challenges in evaluation and management. Endocr Pract 2011;17:807-18.

6. Robert B. Diagnosis and treatment of hirsutism. Hospital Practice 1973;3; 91-98.

7. Kirschner M. Hirsutism and virilism in women. Special topics in endocrinology and metabolism 1984: 55-93. 